Noticias

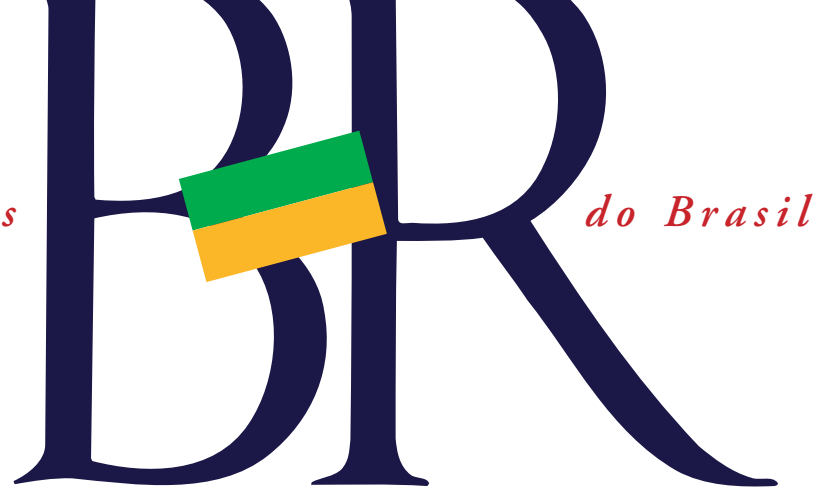

ConstruÇão CIVIL

\title{
Brasil não consegue dar 0 destino adequado para resíduos
}

Apesar da desaceleração do mercado da construção civil devido à crise econômica, 2017 foi um ano de retomada do setor. Segundo dados da Associação Brasileira de Incorporadoras Imobiliárias (Abrainc) e da Fundação Instituto de Pesquisas Econômicas (Fipe), 82.508 imóveis novos foram lançados no país em 2017, uma alta de 18,2\% em relação a 2016.

Se a notícia anima as empreiteiras e o setor imobiliário, a destinação dos resíduos desses empreendimentos preocupa. São os chamados resíduos da construção e demolição (RCD) ou resíduos da construção civil (RCC). Segundo a Associação Brasileira para Reciclagem de Resíduos da Construção Civil e Demolição (Abrecon), esses materiais são gerados no processo construtivo, de reforma, escavação ou demolição e são popularmente compostos por entulho, fragmentos ou restos de tijolo, concreto, argamassa, aço, madeira, entre outros.

Informações da Associação Brasileira de Empresas de Limpeza Pública e Resíduos Especiais (Abrelpe) apontam que, em 2015, foram coletados cerca de 45 milhóes de

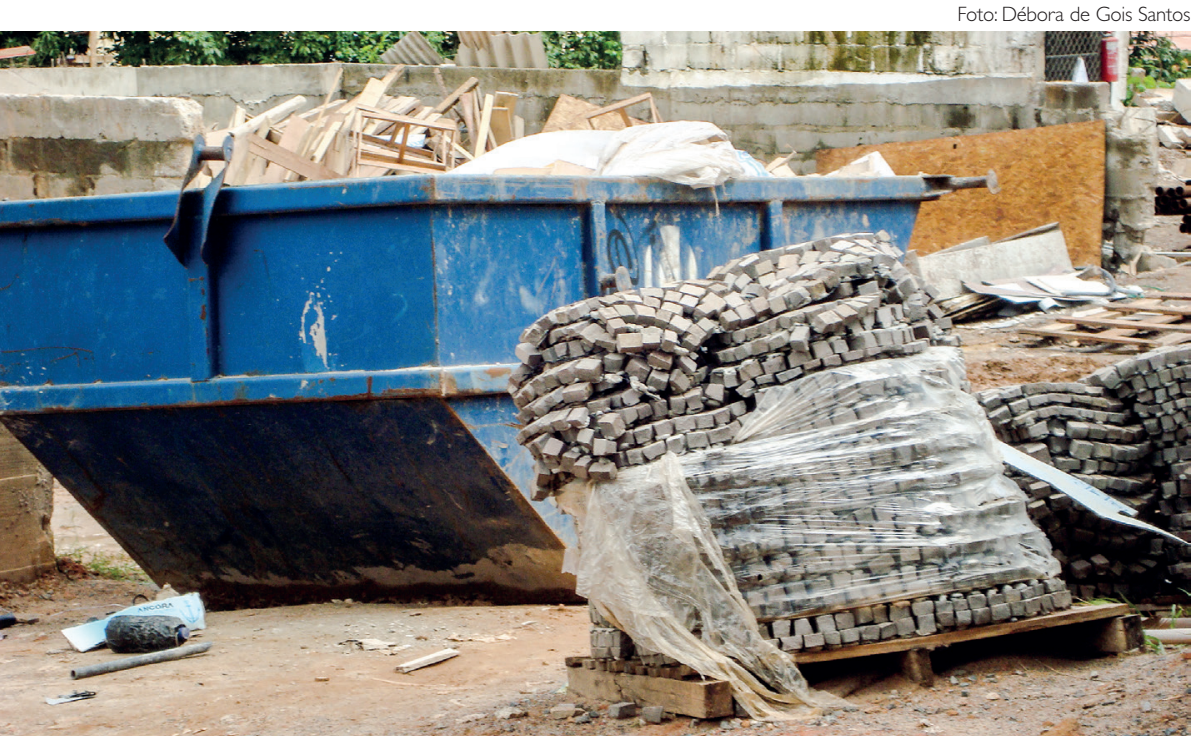

Em cidades de médio e grande porte, resíduos de construção civil e demolição representam de $40 \%$ a $70 \%$ de todos os resíduos

toneladas desses resíduos no Brasil. Entretanto, esse dado é subestimado visto que os municípios, responsáveis por recolher esse material, em geral coletam apenas aqueles lançados ou abandonados nos logradouros públicos. Em cidades brasileiras de médio e grande porte, os originados de construção e demolição representam de $40 \%$ a $70 \%$ de todos os resíduos. "Infelizmente, o Brasil não consegue dar o destino adequado aos resíduos da construção civil. Precisaríamos de uma maior conscientização e de legislação municipal. Temos legislação federal e resolução com força de lei, mas são poucos municípios que possuem legislação própria”, comenta Débora de Gois Santos, professora do Departamento de Engenharia Civil da Universidade Federal de Sergipe (UFS). "Na verdade, a engenharia empregada no Brasil é uma das melhores do mundo; o que está mal resolvido é a saída, é aí que entra a discussão sobre sustentabilidade", observa José da Costa Marques Neto, professor do Departamento de Engenharia Civil da Universidade Federal de São Carlos (UFSCar). Quando descartados inadequadamente, os RCC contaminam o meio ambiente, o que pode inviabilizar o uso do solo para nova construção ou mesmo causar doenças pelo acúmulo indevido. "Para os resíduos classe A (concreto, argamassa, cerâmica, solo, pavimentação), são vários riscos: atração de vetores, como ratos, que podem transmitir doenças; comprometimento dos recursos não re- 
